\title{
Prevalence and predictors of vector-borne pathogens in Dutch roe deer
}

\author{
Sara R. Wijburg1,2, Manoj Fonville², Arnout de Bruin², Piet A. van Rijn ${ }^{3,4}$, Margriet G. E. Montizaan',
} Jan van den Broek ${ }^{5}$, Hein Sprong ${ }^{2}$ and Jolianne M. Rijks ${ }^{{ }^{*}}$

\begin{abstract}
Background: The main objective of this study was to determine the prevalence of nine vector-borne pathogens or pathogen genera in roe deer (Capreolus capreolus) in the Netherlands, and to identify which host variables predict vector-borne pathogen presence in roe deer. The host variables examined were the four host factors 'age category', 'sex,',nutritional condition' and 'health status', as well as 'roe deer density'.

Methods: From December 2009 to September 2010, blood samples of 461 roe deer were collected and analysed by polymerase chain reaction (PCR) for the presence of genetic material from Anaplasma phagocytophilum, Bartonella spp., Babesia spp., Borrelia burgdorferi sensu lato (s.l.), Borrelia miyamotoi, Neoehrlichia mikurensis, Rickettsia spp., and epizootic haemorrhagic disease virus (EHDV), and by commercial enzyme-linked immunosorbent assay (ELISA) for antibodies against bluetongue virus (BTV). The possible associations of host factors and density with pathogen prevalence and co-infection, and in the case of A. phagocytophilum with bacterial load, were assessed using generalized linear modelling.

Results and conclusion: Analysis revealed the following prevalence in roe deer: A. phagocytophilum 77.9\%, Bartonella spp. $77.7 \%$, Babesia spp. 17.4\%, Rickettsia spp. 3.3\%, B. burgdorferi sensu lato $0.2 \%$. Various co-infections were found, of which A. phagocytophilum and Bartonella spp. (49.7\% of infected roe deer) and A. phagocytophilum, Bartonella spp. and Babesia spp. (12.2\% of infected roe deer) were the most common. Anaplasma phagocytophilum, Babesia spp., and co-infection prevalence were significantly higher in calves than in adult roe deer, whereas the prevalence of Bartonella spp. was lower in roe deer in good nutritional condition than in deer in poor nutritional condition. Local roe deer density was not associated with pathogen presence. The high prevalence of A. phagocytophilum, Bartonella spp., and Babesia spp. is evidence for the role of roe deer as reservoirs for these pathogens. Additionally, the results suggest a supportive role of roe deer in the life-cycle of Rickettsia spp. in the Netherlands.
\end{abstract}

Keywords: Capreolus capreolus, Anaplasma phagocytophilum, Babesia, Bartonella, Borrelia, Rickettsia, Neoehrlichia mikurensis, Epizootic haemorrhagic disease virus, Bluetongue virus, Co-infection

\footnotetext{
*Correspondence: j.m.rijks@uu.nl

${ }^{1}$ Dutch Wildlife Health Centre, Department of Biomolecular Health

Sciences, Faculty of Veterinary Medicine, Utrecht University, Utrecht, The Netherlands

Full list of author information is available at the end of the article
}

\section{Background}

Since the 1990s, several vector-borne diseases have been emerging in Europe in both humans and animals [1-4]. This trend is apparent for enzootic diseases such as Lyme borreliosis in humans caused by the tick-borne pathogen Borrelia burgdorferi sensu lato (s.l.), as well as for novel vector-borne diseases such as bluetongue in livestock induced by a virus transmitted via Culicoides midges [5, 6]. Wildlife species affect the emergence of vector-borne original author(s) and the source, provide a link to the Creative Commons licence, and indicate if changes were made. The images or other third party material in this article are included in the article's Creative Commons licence, unless indicated otherwise in a credit line to the material. If material is not included in the article's Creative Commons licence and your intended use is not permitted by statutory regulation or exceeds the permitted use, you will need to obtain permission directly from the copyright holder. To view a copy of this licence, visit http://creativecommons.org/licenses/by/4.0/. The Creative Commons Public Domain Dedication waiver (http://creativeco mmons.org/publicdomain/zero/1.0/) applies to the data made available in this article, unless otherwise stated in a credit line to the data. 
diseases by being more or less competent hosts for vectors and the vector-borne pathogens these transmit [7]. One of these wildlife host species is the roe deer (Capreolus capreolus). Roe deer is the most numerous cervid species in the Netherlands (estimated $>60,000$ in 2008), found throughout the country though predominantly in the eastern part [8].

Roe deer are competent hosts for the vector-borne pathogens Anaplasma phagocytophilum, some Bartonella species and a few Babesia species. Reported $A$. phagocytophilum prevalence in roe deer ranges from 9.6\% in Poland to $98.9 \%$ in Germany [9-17]. Roe deer are mostly infected with the non-zoonotic $A$. phagocytophilum ecotype II, rarely with the zoonotic ecotypes I and III $[16,18,19]$. The main vector of $A$. phagocytophilum in Europe is Ixodes ricinus (Acari: Ixodidae, sheep tick) $[13,20]$, in which no transovarial transmission has been demonstrated to date [21,22]. Between 0 and $10.6 \%$ prevalence was reported in questing $I$. ricinus in the Netherlands $[19,23]$. The Bartonella species found in roe deer include Bartonella capreoli, the zoonotic Bartonella schoenbuchensis and Bartonella bovis [24-26]. Bartonella spp. infection rates reported in roe deer blood samples from Poland ranged between 13.4 and 27.6\% [11, 26]. In Germany, B. schoenbuchensis was isolated from four out of five roe deer [27]. Potential vectors of these bacteria include ticks and keds [24, 28]. The deer ked Lipoptena cervi (Hippoboscidae) is the main vector of $B$. schoenbuchensis [29]. The two most commonly detected Babesia species in roe deer are Babesia capreoli and, to a lesser extent, the zoonotic Babesia venatorum (previously named Babesia sp. EU1) [10, 17, 30-32]. Babesia divergens was occasionally reported in earlier studies, but this could have been Babesia capreoli [31, 33-35]. Incidentally, Babesia bigemina, Babesia sp. MO1 and Babesia microti-like species have also been reported in roe deer [32, 35, 36]. Reported Babesia spp. prevalence in roe deer in Europe ranges from 8.7\% to $89.5 \%$ [10, 17, 35, 37, 38]. Ixodes ricinus is a primary vector of Babesia capreoli and $B$. venatorum in Europe [39, 41]. Transstadial and transovarial transmission occurs for $B$. venatorum, but only transstadial for $B$. microti [30, 41].

Roe deer are considered to be incompetent hosts for B. burgdorferi s.l. $[42,43]$ because of the borreliacidal activity of their innate immune system [42, 43], and are possibly also incompetent hosts for Borrelia miyamoto $i$, the causative agent of relapsing fever in humans [44]. Although they seroconvert upon B. burgdorferi s.l. exposure through tick bites [15], deer are not infective to feeding $I$. ricinus ticks [42]. The role of roe deer in enhancing the emergence of Lyme borreliosis has been associated with their importance as a propagation host for I. ricinus rather than as a reservoir of the pathogen [2,
5]. In addition, roe deer are unlikely to be an important reservoir of Neoehrlichia mikurensis. Limited research on potential host species of $N$. mikurensis suggests that rodents are the natural reservoir $[45,46]$. Ixodes ricinus is the vector of these three pathogens, with $B$. burgdorferi s.l. being detected in $11.8 \%$ of the questing nymphs and adults in the Netherlands [23], B. miyamotoi in 2.9\% [44] and N. mikurensis in $5.6-11 \%[23,47]$.

The competence of roe deer as hosts of Rickettsia spp. causing spotted fever syndrome is unclear [48]. Blood samples from 4 out of $21(19 \%)$ roe deer from the period 2000-2002 in the Netherlands tested positive for Rickettsia helvetica [48]. These four deer were not reported to have clinical signs [48]. Rickettsia helvetica is one of the two main spotted fever Rickettsia transmitted by I. ricinus in Europe, with tick infection rates in the Netherlands ranging from 6 to $66 \%$ [48].

Roe deer can be infected with the Culicoides-borne orbiviruses bluetongue virus (BTV) and epizootic haemorrhagic disease virus (EHDV) $[6,49,50]$. BTV seroprevalence studies in Spain, France and Belgium showed that after BTV introduction, antibodies were present in $1.2 \%$ (France) up to $5.1 \%$ (Spain) of the roe deer $[6,49]$. BTV is not enzootic in the Netherlands, but an epidemic (BTV-8 epidemic 2006-2008) and incidental (BTV-6 in 2008) introductions have been recorded in livestock [6]. Roe deer have shown no clinical signs but had viraemia after being experimentally infected with EHDV [50]. The viraemia was lower in roe deer than in other cervid species [50]. There are no known incursions of EHDV into Europe, but the disease is present in cattle in North Africa and the Middle East [51].

To date, no studies have investigated the prevalence of these nine vector-borne pathogens or pathogen genera (for simplicity referred to as pathogens from this point forward) in Dutch roe deer. The aim of this crosssectional study was therefore to determine the apparent prevalence and co-infection of these nine vector-borne pathogens in roe deer blood in the Netherlands and to identify which host variables predict their presence in roe deer.

\section{Methods}

\section{Cross-sectional blood sampling of roe deer}

Blood samples were collected during the doe-and-calf hunting season (December 2009 to March 2010) and the buck hunting season (April 2010 to September 2010). Sampling packages were assigned to game management units (GMUs) at the beginning of each of these two hunting seasons (500 in December 2009; 200 in April 2010), using a random sampling scheme based on the number of roe deer counted in total $(n=57,264)$ and per GMU in 2008 and on the overall composition of this count 
(44\% does and $26 \%$ calves, 30\% bucks). Hunters were requested to collect blood samples post-mortem from the vessels in the neck, axilla or inguina, the heart, the chest cavity or abdominal cavity of hunted roe deer, by using serum and ethylenediaminetetraacetic acid (EDTA)-blood syringes of the S-Monovette collection system (Sarstedt, Nümbrecht, Germany) without needles. Moreover, the hunters noted information regarding the approximate age of the animals (calf, yearling, adult), sex (female, male), nutritional condition (poor, moderate, good), health status (ill health, healthy) and the exact weight (indicating if weighed with or without head and or legs). A calf is a deer $<1$ year of age, a yearling is between 1 and 2 years old, and adult roe deer are deer older than 2 years. This information was sent with the blood samples to the Dutch Wildlife Health Centre, where the samples were divided into aliquots and kept frozen $\left(-80{ }^{\circ} \mathrm{C}\right)$ until further processing. In total, 461 (65.9\%) samples were returned and suitable for pathogen detection: 344 obtained in the doe-and-calf hunting season (return rate $68.8 \%, 344 / 500$ ), and 117 in the buck hunting season (return rate $58.5 \%, 117 / 200$ ).

\section{Detection of vector-borne bacteria and protozoa}

DNA from blood samples was extracted using the DNeasy ${ }^{\circledR}$ Blood \& Tissue kit (QIAGEN, Hilden, Germany) as per the manufacturer's instructions. To detect potential cross-contamination negative controls were included in each batch of extraction. Samples were tested with quantitative polymerase chain reaction (qPCR) for the presence of $A$. phagocytophilum [19], B. burgdorferi s.l. [52], B. miyamotoi [53], spotted fever Rickettsia [54] and N. mikurensis [47]. For detection of Babesia spp. a conventional PCR assay was used, which targets a fragment of the Babesia 18S rDNA of several Babesia spp. [55]. Bartonella spp. DNA was detected by PCR as previously described [28]. The PCR products were analysed with gel electrophoresis on a 1.5\% agarose gel and coloured with SYBR ${ }^{\mathrm{TM}}$ Gold Nucleic Acid Gel Stain (Invitrogen, Carlsbad, CA, USA). Positive controls and negative water controls were used on every plate tested. To minimize contamination and false-positive samples, the DNA extraction, PCR mix preparation, sample addition and (q)PCR analyses were performed in separate air-locked dedicated labs. Sequencing of positive Bartonella and Babesia samples followed conventional PCR for species identification, i.e., for Bartonella, DNA sequencing of a 380-base-pair (bp) fragment of the citrase synthase gene [56], and for Babesia, sequencing of a $\sim 400 \mathrm{bp}$ fragment of the 18S rDNA [55]. Bartonella and Babesia species identification was determined using BLAST (Basic Local Alignment Sequencing Tool), and by using
Bionumerics 7.5 for comparisons to in-house molecular databases and to sequences obtained from NCBI.

\section{Detection of vector-borne viruses}

For the detection of EHDV RNA, $125 \mu \mathrm{l}$ blood was diluted to $250 \mu \mathrm{l}$, from which $200 \mu \mathrm{l}$ was then taken to extract genetic material using the MagNAPure Total NA isolation kit (Roche Diagnostics GmbH, Mannheim, Germany). The genetic material was extracted in $50 \mu \mathrm{l}$ of RNAse-free water, of which $5 \mu \mathrm{l}$ was then pooled with that of four other samples for use in the PCR test. If positive, the samples of that pool would then be tested separately. The PCR test was a modified real-time RT-PCR test based on the Kit TaqVet ${ }^{\circledR}$ epizootic haemorrhagic disease virus kit (LSI, Lissieu, France). A commercial ELISA was used to detect BTV-reactive antibodies in roe deer serum (or plasma) samples (IDvet, Montpellier, France). Samples from the doe-and-calf hunting season would be tested first for these two orbiviruses and those from the buck hunting season only if samples from the doe-and-calf hunting season tested positive.

\section{Statistical analyses Sample characteristics}

Host factor categories were plotted per month for insight into their temporal distribution, and count differences in host factors per hunting season were investigated using the Chi-square test $\left(x^{2}\right)$ or the Fisher's exact test. A Chisquare test was also performed for comparison of the proportions of calves (female calves and male calves), does (yearling and adult females) and bucks (yearling and adult males) in the sample to those in the counted roe deer population.

The spatial distribution of the samples was mapped against five roe deer density classes in GMUs using ArcGIS 10.5.1 (Esri, 2017): $0 ;>0$ and $\leq 2 ;>2$ and $\leq 4 ;>4$ and $\leq 6$; and $>6$ roe deer per $100 \mathrm{ha}$. GMU roe deer density was calculated by dividing the number of roe deer counted in the GMU in 2008 by the surface of the GMU; both the nominator and the denominator were provided by the Royal Dutch Hunters' Association (KNJV). To investigate whether the spatial distribution of the samples was significantly related to GMU deer density, a linear regression (LR) model was fitted to quantify the effect of GMU roe deer density on the number of samples supplied by the different GMUs. GMUs where no roe deer were counted or where hunting was not authorized were removed (76/318) in advance. The mean density of the roe deer in the sample was compared to the mean density of roe deer in the 242 GMUs by $t$-test, and if different, investigated further by comparing density class distributions. 
The correspondence of body mass to the four roe deer host factors and density was examined by fitting a multiple linear regression (MLR) model to quantify the effect of these parameters on body mass, using 'calf', 'female', 'poor nutritional condition' and 'ill-health' as reference categories for the categorical data. The sign of the estimate and statistical significance of each host factor in the expected direction for body mass was used as global verification of the host factor data submitted by the hunters.

\section{Pathogen (sero-)prevalence, spatio-temporal distributions and co-infection}

Apparent prevalence was determined for A. phagocytophilum, Babesia spp., Bartonella spp., B. burgdorferi s.l., B. miyamotoi, EHDV, N. mikurensis, Rickettsia spp. and seroprevalence for BTV. Diagnostic test results were used to generate presence and absence maps per pathogen and hunting season distributions.

Subsequently, pathogen co-infections were quantified. A two-by-two comparison of pathogens using the $x^{2}$ test or Fisher's exact test was performed to assess whether the number of co-infections observed could be explained by chance. For the determination of the association between the presence of a given pathogen and the presence of the other investigated pathogens, a generalized linear model (GLM) was performed, with a binomial distribution in regard to pathogen presence or not.

\section{Association of pathogens with roe deer host factors and density}

For the determination of the association between the presence of vector-borne pathogens and the host factors (age category, sex, nutritional condition, health status) and density, a GLM regression was performed. If relevant, a second GLM model was fitted to obtain the effect of host factors and density on pathogen load $\left(\mathrm{C}_{\mathrm{q}}\right.$-value $)$. Because no reference DNA was used to validate each individual $\mathrm{C}_{\mathrm{q}}$-value, $\mathrm{C}_{\mathrm{q}}$-value was included as binary response variable with an arbitrary cut-off value of 30 (1 if $\mathrm{C}_{\mathrm{q}}$-value $\leq 30$; 0 if $\mathrm{C}_{\mathrm{q}}$-value $>30$ ). Similar analyses were performed for the presence of co-infections in relation to host factors and density (GLM), and for the effect of host factors and density on the number of different co-infecting pathogens present in roe deer.

All statistical analyses were conducted in $R$ ( $R$ version 4.0.0 [2020-04-24]). Predictors were selected by backward stepwise selection, using the Akaike information criterion (AIC) value for selection of the model with the best fit. Models were run using subsets of data with values for the dependent and all the predictor variables. The retained models were checked for multicollinearity based on the variation inflation factor (VIF), normality and homoscedasticity. The level of statistical significance in all tests was set at $P=0.05$. The databases and R-script are available as supplementary material (Additional files $1,2$ and 3$)$.

\section{Results}

\section{Sample characteristics and identification of possible sources of bias}

The blood samples were obtained from 461 roe deer of different age categories (145 calf, 105 yearling, 204 adult, 7 not available; NA), sex (304 female, 155 male, 2 NA), nutritional condition (38 poor, 376 moderate, 40 good, 7 NA) and health status (404 healthy, 19 ill, 38 NA) (Additional file 1: sample database). Age and sex categories expectedly showed a pattern consistent with the differential hunting seasons (Fig. 1a, Chi-square test for age category, $x^{2}=63.36, d f=2, P<0.001$; Fig. $1 \mathrm{~b}$, Chi-square test for sex, $\left.X^{2}=304.01, d f=1, P<0.001\right)$. No significant differences were detected between the two hunting seasons in the nutritional condition (Fig. 1c; Chi-square test, $x^{2}=3.19, d f=2, P=0.203$ ) or in health status (Fig. 1d; Fisher's exact test, $P=0.054$, odds ratio $[\mathrm{OR}]=6.3,95 \%$ confidence interval $[\mathrm{CI}]=1-265)$. Compared to the proportions in the counted population (26\% calves, $44 \%$ does, $30 \%$ bucks), the proportion of calves in the sample was slightly overrepresented $(31.9 \%, 144 / 452)$ at the cost of bucks $(26.3 \%, 119 / 452)$ and to lesser extent does $(41.8 \%, 189 / 452)$ (Chi-square test, $\chi^{2}=8.49, d f=2$, $P=0.014)$.

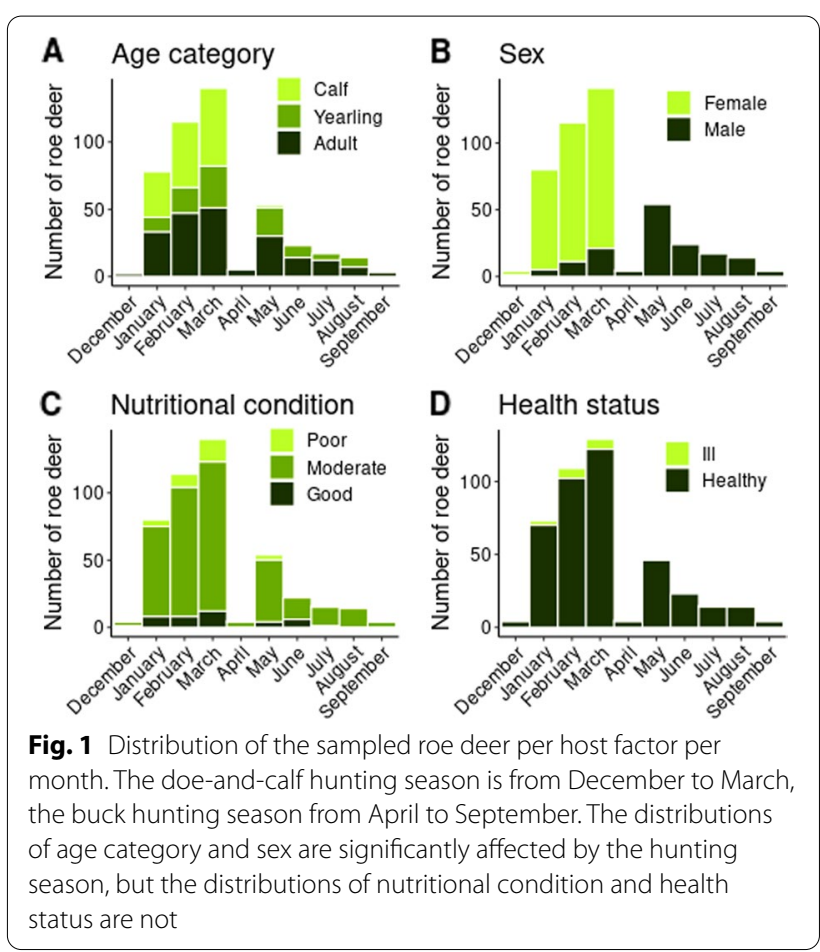


The spatial distribution of the samples mapped against roe deer density classes is shown in Fig. 2a. Roe deer densities in the 242 GMUs ranged from 0.06 to 10.36 roe deer per 100 ha (Additional file 2: GMU database). The number of samples provided by a GMU significantly increased with GMU roe deer density (estimate $\left.\pm \mathrm{SE}=0.544 \pm 0.092 ; \quad F_{(1,240)}=34.93, \quad P<0.001\right)$, but the model had a poor fit (adjusted $R^{2}=12.3 \%$ ). The mean \pm SD roe deer density per 100 ha in the sampled population $(3.41 \pm 1.74)$ was significantly higher than the mean for the 242 GMUs $\left(2.55 \pm 1.74 ; t\right.$-test, $t_{(490)}=6.248$, $P=<0.001)$. The density category proportions differed significantly between sample and the 242 GMUs (Chisquare test, $x^{2}=43.73, d f=3, P<0.001$ ), with an underrepresentation of roe deer from GMUs with $\leq 2$ roe deer per 100 ha in the sample (Fig. 2b).

Body weight ranged from $7.0 \mathrm{~kg}$ to $22.0 \mathrm{~kg}$ for females and from $7.0 \mathrm{~kg}$ to $23.0 \mathrm{~kg}$ for males. The model for body weight had a good fit (adjusted $R^{2}=67.2 \%$ ) and maintained all five investigated host variables, with body weight being significantly positively associated with increasing age, male sex, better nutritional condition and healthy status, and significantly negatively associated with increasing roe deer density (Table 1). Details on mean body weight per sex-age category are provided as supplementary information (Additional file 4).

\section{Pathogen (sero-)prevalence, spatio-temporal distributions and co-infection}

Genetic material of at least one of the investigated pathogens was detected in a high proportion of the roe deer sampled $(92.0 \%, 424 / 461)$ (Table 2). DNA of $A$. phagocytophilum was detected in $77.9 \%$ (95\% CI 73.7-81.5) of the samples, Bartonella spp. in 77.7\% (95\% CI 73.5-81.3), Babesia spp. in 17.4\% (95\% CI 14.1-21.2) and Rickettsia spp. in 3.3\% (95\% CI 1.9-5.4) (Table 2). Positive samples occurred widespread throughout the country in the roe deer population (Fig. 3). There were no significant temporal differences except for Babesia spp., which was less frequently detected in the buck hunting season (Chisquare test, $\left.x^{2}=9.32, d f=1, P=0.002\right)$. Only one animal tested positive for $B$. burgdorferi s.l. by qPCR. Several attempts to confirm the presence of B. burgdorferi s.l. DNA by conventional PCR of a small fragment of the intergenic spacer region were unsuccessful [57]. None of the 461 roe deer tested positive for the presence of $B$. miyamotoi or $N$. mikurensis DNA. In addition, none of the roe deer sampled in the doe-and-calf period tested positive for EHDV RNA $(n=344)$ or showed evidence for BTV antibodies ( $n=338 ; 6 \mathrm{NA})$.

DNA sequencing a $\sim 380 \mathrm{bp}$ fragment of the citrase synthase gene from 47/358 Bartonella spp. positive samples indicated the presence of $B$. schoenbuchensis
(21/47, 44.7\%) and Bartonella capreoli (5/47, 10.6\%), while unsuccessful for 21 samples $(21 / 47,44.7 \%)$. The $B$. schoenbuchensis sequences were more than $99 \%$ similar to B. schoenbuchensis found in Germany (Genbank accession numbers AJ564632 and AJ564633). The five Bartonella capreoli sequences were more than $98 \%$ similar to the Bartonella capreoli found in roe deer from Poland (JQ929915) and France (AF293392). Sequencing a 400 bp fragment of the 18S rDNA of the 80 Babesia positive samples showed the presence of Babesia capreoli $(27 / 80,33.75 \%)$ and B. microti $(3 / 80,3.75 \%)$, while unsuccessful in 50 samples $(50 / 80,62.5 \%)$. The Babesia capreoli sequences were more than $99 \%$ similar to the Babesia capreoli from roe deer (AY726009) or I. ricinus (FJ215873) from France. The three B. microti sequences were more than $99.5 \%$ similar to the $B$. microti found in I. ricinus from Switzerland (AF494286) and Slovenia (AF373332). Sequences from this study can be found in Additional file 5.

Vector-borne pathogen co-infection was detected in $69.2 \%(319 / 461)$ of the samples. The most common coinfection combinations observed in the sample were $A$. phagocytophilum and Bartonella spp. and A. phagocytophilum, Bartonella spp. and Babesia spp. (Table 2). All other combinations each represented only small percentages (Table 2). Co-infections involving $A$. phagocytophilum and Bartonella spp. occurred more frequently than could be expected by chance, as did co-infections involving A. phagocytophilum and Babesia spp. (Table 3). The positive associations of $A$. phagocytophilum with Bartonella spp. and Babesia spp., of Bartonella spp. with A. phagocytophilum, and of Babesia spp. with A. phagocytophilum were further confirmed by the GLM results (Table 4).

\section{Pathogen associations with roe deer host factors and density}

The prevalence of pathogens per host factor category is summarized in Table 5 . The presence of A. phagocytophilum DNA was associated with age category only, with adult roe deer having significantly lower odds of testing

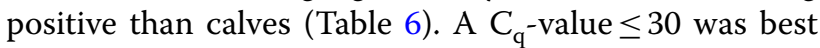
predicted by a model including age category and sex, the odds significantly decreasing with being adult and increasing with being male (Table 7).

The presence of Bartonella spp. was best predicted by a model with only nutritional condition. While not statistically significant, the odds of testing positive for Bartonella spp. were lower in roe deer in good condition compared to those in poor condition (Table 6).

The presence of Babesia spp. was best predicted by a model including the age category and health, with both 


\section{A - Sampled roe deer Province borders}

Roe deer density per 100 ha

0
$>0$ and $<=2$
$>2$ and $<=4$
$>4$ and $<=6$
$>6$

No hunting (not
authorized, not
performed, or urban
area)
No count information
(usually because no
roe deer)
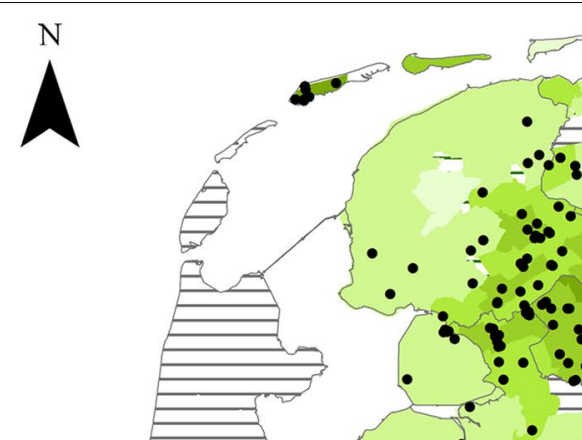
Table 1 Host factor and density predictors of roe deer body weight $(n=329)$

\begin{tabular}{|c|c|c|c|c|}
\hline Dependent variable & Model structure ${ }^{a}$ & Estimate $\pm \mathrm{SE}$ & $t$ & $P$ \\
\hline \multirow[t]{8}{*}{ Roe deer body weight } & Intercept & $7.549(0.513)$ & 14.705 & $<0.001^{*}$ \\
\hline & Age category-yearling & $2.845(0.280)$ & 10.167 & $<0.001^{*}$ \\
\hline & Age category_adult & $4.783(0.231)$ & 20.691 & $<0.001^{*}$ \\
\hline & Sex-male & $0.776(0.213)$ & 3.645 & $<0.001^{*}$ \\
\hline & Nutritional condition-moderate & $2.151(0.467)$ & 4.602 & $<0.001^{*}$ \\
\hline & Nutritional condition—good & $3.875(0.568)$ & 6.820 & $<0.001^{*}$ \\
\hline & Health status—-healthy & $1.584(0.584)$ & 2.713 & $0.007^{*}$ \\
\hline & Density & $-0.164(0.056)$ & -2.916 & $0.004^{*}$ \\
\hline
\end{tabular}

${ }^{a}$ Predicted effect of age category (calf, yearling, adult), sex (female, male), nutritional condition (poor, moderate, good) and health (ill, healthy) on the variable body weight, subset data $(n=329)$. Model reference categories: age category: calf; sex: female; nutritional condition: poor; health status: ill

*Statistically significant

Table 2 Prevalence of single pathogen infections and different combinations of two- and three-pathogen co-infections $(n=461)$

\begin{tabular}{lll}
\hline $\begin{array}{l}\text { No. of } \\
\text { pathogens }\end{array}$ & Pathogen species & No. of roe deer (\%) \\
\hline 0 & - & \\
1 & Rickettsia & $37(8.0 \%)$ \\
& Babesia & $1(0.2 \%)$ \\
& Anaplasma & $2(0.4 \%)$ \\
& Bartonella & $49(10.6 \%)$ \\
& Subtotal & $53(11.5 \%)$ \\
& Bartonella \& Rickettsia & $105(22.8 \%)$ \\
& Anaplasma \& Rickettsia & $1(0.2 \%)$ \\
& Bartonella \& Babesia & $3(0.7 \%)$ \\
& Anaplasma \& Babesia & $8(1.7 \%)$ \\
& Anaplasma \& Bartonella & $11(2.4 \%)$ \\
& Subtotal & $229(49.7 \%)$ \\
& Anaplasma \& Bartonella \& Borrelia & $252(54.7 \%)$ \\
& Anaplasma \& Bartonella \& Rickettsia & $7(0.2 \%)$ \\
& Anaplasma \& Bartonella \& Babesia & $56(12.2 \%)$ \\
& Subtotal & $64(13.9 \%)$ \\
& Anaplasma \& Bartonella \& Babesia \& & $3(0.7 \%)$ \\
& Rickettsia & \\
\hline
\end{tabular}

yearling and adult animals having significantly lower odds of testing positive than calves (Table 6).

The presence of Rickettsia spp. was best predicted by a model including age category and health. Despite a $P$-value suggesting significantly lower odds for Rickettsia spp. in healthy compared to ill roe deer, this effect of the factor health was not substantiated by the confidence interval (Table 6).

The occurrence of co-infection was associated with the host age category, with adult roe deer having significantly lower odds of having co-infections than calves (Table 6).
The number of co-infecting pathogens was best predicted by a model including age category and health, with a significant negative effect of being adult (Table 8).

\section{Discussion}

In this cross-sectional study from 2010, five of the nine investigated vector-borne pathogens were detected in the Dutch roe deer population. Roe deer harboured $A$. phagocytophilum, Bartonella spp., Babesia spp., Rickettsia spp. and B. burgdorferi s.l. There was no evidence for infection with $B$. miyamotoi, $N$. mikurensis or EHDV, nor was there any serological evidence for exposure to BTV. Most of the vector-borne pathogen-positive roe deer were co-infected with both $A$. phagocytophilum and Bartonella spp., followed by triple infection with $A$. phagocytophilum-Bartonella spp.-Babesia spp. The prevalence of A. phagocytophilum, Babesia spp. and co-infections was highest in calves. The prevalence of Bartonella spp. was highest in roe deer in poor nutritional condition.

The DNA of $A$. phagocytophilum was found in $77.9 \%$ of the samples. This relatively high prevalence supports a primary role of roe deer in the maintenance of $A$. phagocytophilum in the Netherlands [58]. However, this is presumably the commonly detected non-zoonotic ecotype II $[16,18,19,59,60]$. Anaplasma phagocytophilum causes disease by infecting phagocytic cells, mainly neutrophils, in which it replicates and spreads to tissues [20]. Current knowledge indicates that infection is often subclinical, but clinical disease can occur, in particular in young or naïve animals $[20,61]$. The odds of detecting $A$. phagocytophilum were significantly greater in calves than in adult animals. This suggests $A$. phagocytophilum infection may be less present in animals $>2$ years old. Alternatively, some adults may have acquired premunition with a level of infection that is reduced to below the limit of detection by PCR. Finding that $\mathrm{C}_{\mathrm{q}}$-value $\leq 30$ (high pathogen load) negatively associated with older age indicates lower 


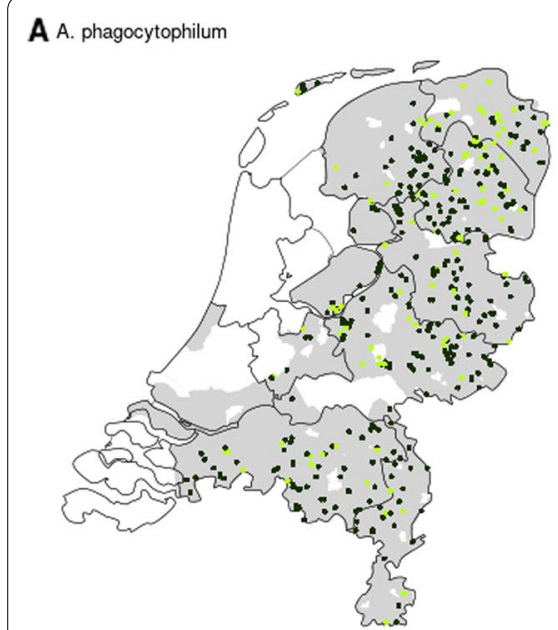

D Rickettsia spp.

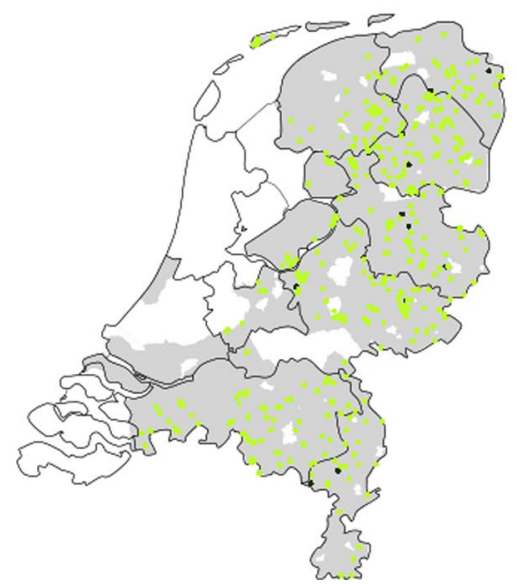

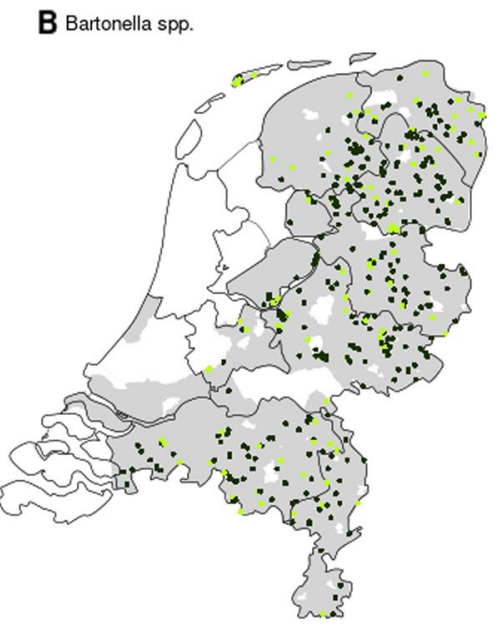

E B. burgdorferi s.l.

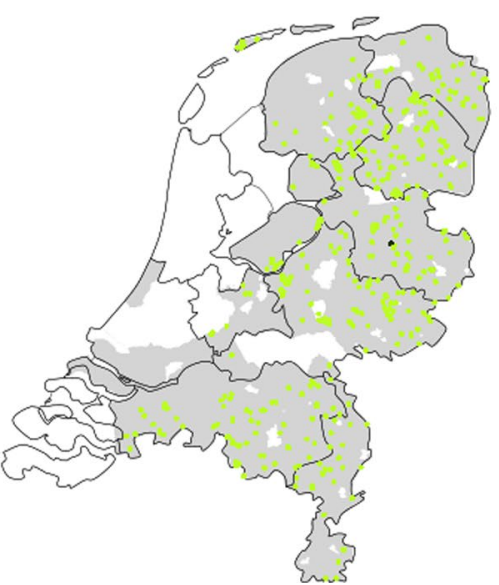

C Babesia spp.

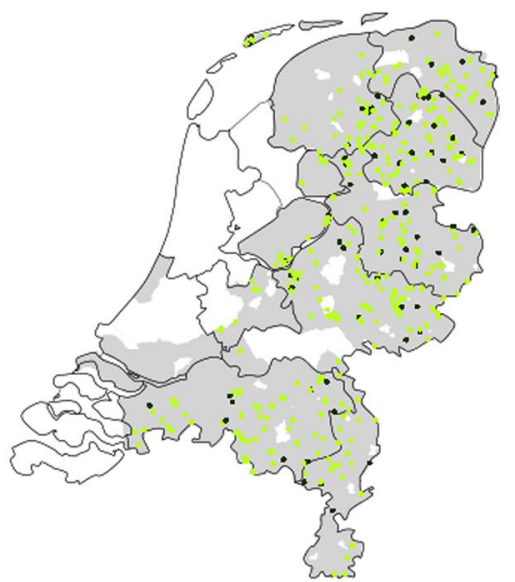

F Co-infection

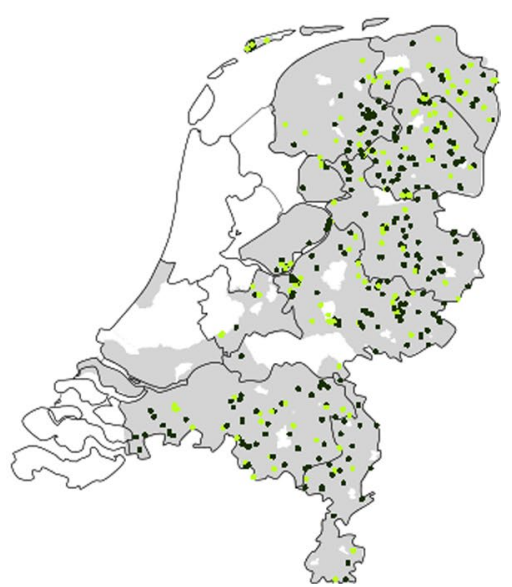

Fig. 3 Presence and absence of vector-borne pathogens and co-infection in the Netherlands $(n=461)$. a Sample distribution of $A$. phagocytophilum. b Sample distribution of Bartonella spp. c. Sample distribution of Babesia spp. d Sample distribution of Rickettsia spp. e Sample distribution of B. burgdorferi s.l. f Presence of co-infection. The dark green dots represent vector-borne pathogen presence, and the light dots represent vector-borne pathogen absence

Table 3 Probability of co-infections occurring by chance $(n=461)$

\begin{tabular}{llll}
\hline & Bartonella spp. & Babesia spp. & Rickettsia spp. \\
\hline A. phagocytophilum & $\mathrm{O}^{\mathrm{a}: 296(64.2 \%)}$ & $\mathrm{O}: 70(15.2 \%)$ & $\mathrm{O}: 13(2.8 \%)$ \\
& $\mathrm{E}^{\mathrm{b}}: 278.79(60.5 \%)$ & $\mathrm{E}: 62.29(13.5 \%)$ & $P=0.539, \mathrm{OR}=1.9,95 \% \mathrm{Cl}=0-17$ \\
& $\mathrm{X}^{2}=20.26, d f=1, P<0.001^{* \mathrm{c}}$ & $\mathrm{X}^{2}=4.55, d f=1, P=0.033^{*}$ & $\mathrm{O}: 11(2.4 \%)$ \\
& & $\mathrm{O}: 67(14.5 \%)$ & $\mathrm{E}: 11.65(2.5 \%)$ \\
Bartonella spp. & $\mathrm{E}: 62.13(13.5 \%)$ & $P=0.752, \mathrm{OR}=0.78,95 \% \mathrm{Cl}=0-3$ \\
& $\mathrm{X}^{2}=1.67, d f=1, P=0.197$ & $\mathrm{O}: 3(0.65 \%)$ \\
Babesia spp. & & $\mathrm{E}: 2.6(0.56 \%)$ \\
& & $P=0.732, \mathrm{OR}=0.78,95 \% \mathrm{Cl}=0-3$
\end{tabular}

\section{${ }^{\text {a }}$ Observed}

${ }^{\mathrm{b}}$ Expected

' $P$-value as determined by Chi-square test (A. phagocytophilum, Babesia spp., Bartonella ssp.) or Fisher's exact test (Rickettsia spp.)

*Statistically significant 
Table 4 Co-infecting pathogen predictors for the investigated pathogens $(n=461)$

\begin{tabular}{|c|c|c|c|c|c|}
\hline Dependent variable & Model structure ${ }^{a}$ & Estimate $( \pm$ SE) & $z$ & $P$ & Odds ratio $(95 \% \mathrm{Cl})$ \\
\hline \multirow[t]{3}{*}{ A. phagocytophilum } & Intercept & $0.370(0.207)$ & 1.791 & 0.073 & $1.4(1.0-2.2)$ \\
\hline & Bartonella spp. & $1.081(0.247)$ & 2.018 & $<0.001^{*}$ & $2.9(1.8-4.8)$ \\
\hline & Babesia spp. & $0.735(0.364)$ & 4.374 & $0.044^{*}$ & $2.1(1.1-4.5)$ \\
\hline \multirow[t]{2}{*}{ Bartonella spp. } & Intercept & $0.438(0.203)$ & 2.161 & $0.031^{*}$ & $1.5(1.0-2.3)$ \\
\hline & A. phagocytophilum & $1.109(0.246)$ & 4.513 & $<0.001^{*}$ & $3.0(1.9-4.9)$ \\
\hline \multirow[t]{2}{*}{ Babesia spp. } & Intercept & $-2.219(0.333)$ & -6.666 & $<0.001^{*}$ & $0.1(0.1-0.2)$ \\
\hline & A.phagocytophilum & $0.801(0.359)$ & 2.234 & $0.026^{*}$ & $2.2(1.1-4.8)$ \\
\hline
\end{tabular}

a Predicted effect of other pathogens on prevalence A. phagocytophilum, Bartonella spp., Babesia spp. and Rickettsia spp

*Statistically significant

Table 5 Prevalence of the four most prevalent vector-borne pathogens in roe deer by host age category, sex, nutritional condition and health status

\begin{tabular}{llllll}
\hline Host factor & $\begin{array}{l}\text { Host factor category } \\
\text { (sample size) }\end{array}$ & $\begin{array}{l}\text { Pathogen prevalence }(\%) \\
(95 \% \text { Cl) } \\
\text { A. phagocytophilum }\end{array}$ & Bartonella spp. & Babesia spp. & Rickettsia spp. \\
\hline Age category & Calf $(n=145)$ & $85.5(78.5-90.6)$ & $78.6(70.9-84.8)$ & $25.5(18.8-33.5)$ & $3.4(1.3-8.3)$ \\
& Yearling $(n=105)$ & $77.1(67.7-84.5)$ & $77.1(67.7-84.5)$ & $15.2(9.2-23.9)$ & $5.7(2.3-12.5)$ \\
& Adult $(n=204)$ & $73.0(66.3-78.8)$ & $77.5(71.0-82.9)$ & $12.7(8.6-18.3)$ & $1.5(0.4-4.6)$ \\
Sex & Female $(n=304)$ & $76.6(71.4-81.2)$ & $76.0(70.7-80.6)$ & $19.1(14.9-24.0)$ & $3.6(1.9-6.6)$ \\
Nutritional condition & Male $(n=155)$ & $80.6(73.4-86.3)$ & $80.6(73.4-86.4)$ & $14.2(9.3-20.9)$ & $2.6(0.8-6.9)$ \\
& Poor $(n=38)$ & $73.7(56.6-86.0)$ & $86.8(71.1-95.0)$ & $15.8(6.6-31.9)$ & $10.5(3.4-25.7)$ \\
Health status & Moderate $(n=376)$ & $79.3(74.7-83.1)$ & $77.6(73.0-81.7)$ & $17.8(14.2-22.1)$ & $2.7(1.4-5.0)$ \\
& Good $(n=40)$ & $67.5(50.8-80.9)$ & $70.0(53.3-82.9)$ & $10.0(3.3-24.6)$ & $2.5(0.1-14.7)$ \\
& III $(n=19)$ & $73.7(48.6-89.9)$ & $84.2(59.5-95.8)$ & $31.6(13.6-56.5)$ & $10.5(1.8-34.5)$ \\
\hline
\end{tabular}

A. phagocytophilum loads in adult roe deer and supports premunition in mature animals. Prevalence of $A$. phagocytophilum did not differ between sexes, but the quantity of $A$. phagocytophilum DNA tended to be greater in positive samples from males compared to females. This suggests no sex difference in minimal exposure for detectable infection but rather points to a greater intensity level of pathogen exposure, reduced immunocompetence, or both in males. Due to the differential hunting seasons, males were sampled mostly when there was greater tick activity [62] and during mating season. Mating has been associated with reduced immunological defences in male ungulates [63]. Previous studies found no association between $A$. phagocytophilum prevalence and age and sex of hosts $[10,14,15,17,18]$.

Bartonella spp. DNA was detected with an overall prevalence of $77.7 \%$, which is at the upper end of the range found in Europe [11, 26, 27]. Further sequencing of 13.1\% Bartonella spp.-positive samples showed the presence of B. schoenbuchensis and Bartonella capreoli. Bartonella spp. infection can cause long-lasting intraerythrocytic bacteraemia and endotheliotropic infection but is usually not associated with disease [24, 27]. However, vascular pathology can develop in a small subset of individuals and in accidental hosts [24]. The high prevalence of Bartonella spp. in healthy roe deer could implicate roe deer are chronically bacteraemic and a natural reservoir for Bartonella spp. in the Netherlands. The best model for the presence of Bartonella spp. included only the host nutritional condition, with the presence of Bartonella spp. in roe deer becoming less likely as nutritional condition improved. Establishment of Bartonella spp. infection could be enhanced by poor condition of hosts, either directly by reduced immunocompetence or indirectly via a greater vector infestation and increased exposure to Bartonella spp. Further studies are needed to acquire more solid conclusions about this association.

Babesia spp. DNA was present in $17.4 \%$ of the roe deer, at the lower end of the range documented in Europe [10, $17,35,37,38]$. Babesia spp. are intraerythrocytic parasites, and clinical manifestations can occur in naïve animals or when latent infections flare up under stressful conditions $[39,61]$. Upon sequence analysis, $B$. capreoli was identified, as well as unexpected species, such as $B$. 
Table 6 Host factor and density predictors for the investigated pathogens and co-infection $(n=409)$

\begin{tabular}{|c|c|c|c|c|c|}
\hline Dependent variable & Final model $^{a}$ & Estimate $( \pm S E)$ & $z$ & $P$ & Odds ratio $(95 \% \mathrm{Cl})$ \\
\hline \multirow[t]{3}{*}{ A. phagocytophilum } & Intercept & $1.774(0.248)$ & 7.150 & $<0.001^{*}$ & $5.9(3.1-9.9)$ \\
\hline & Age category-yearling & $-0.602(0.348)$ & -1.731 & 0.083 & $0.5(0.3-1.1)$ \\
\hline & Age category_adult & $-0.725(0.300)$ & -2.422 & $0.015^{*}$ & $0.5(0.3-0.9)$ \\
\hline \multirow[t]{3}{*}{ Bartonella spp. } & Intercept & $2.234(0.607)$ & 3.677 & $<0.001^{*}$ & $9.3(3.3-39.0)$ \\
\hline & Nutritional condition-moderate & $-0.971(0.621)$ & -1.563 & 0.118 & $0.4(0.1-1.1)$ \\
\hline & Nutritional condition-good & $-1.336(0.705)$ & -1.895 & 0.058 & $0.3(0.1-0.9)$ \\
\hline \multirow[t]{4}{*}{ Babesia spp. } & Intercept & $-0.270(0.527)$ & -0.513 & 0.608 & $0.8(0.3-2.1)$ \\
\hline & Age category_yearling & $-0.741(0.361)$ & -2.053 & $0.040^{*}$ & $0.5(0.2-0.9)$ \\
\hline & Age category_adult & $-0.862(0.297)$ & -2.901 & $0.004^{*}$ & $0.4(0.2-0.8)$ \\
\hline & Health status — healthy & $-0.830(0.523)$ & -1.586 & 0.113 & $0.4(0.2-1.3)$ \\
\hline \multirow[t]{4}{*}{ Rickettsia spp. } & Intercept & $-2.178(0.884)$ & -2.463 & $0.014^{*}$ & $0.1(0.0-0.5)$ \\
\hline & Age category-yearling & $1.220(0.737)$ & 1.654 & 0.098 & $3.4(0.8-16.9)$ \\
\hline & Age category_adult & $-0.359(0.830)$ & -0.433 & 0.665 & $0.7(0.1-3.9)$ \\
\hline & Health status_-healthy & $-1.796(0.848)$ & -2.118 & $0.034^{*}$ & $0.2(0.0-1.2)$ \\
\hline \multirow[t]{3}{*}{ Co-infection } & Intercept & $1.171(0.206)$ & 5.697 & $<0.001^{*}$ & $3.2(2.2-4.9)$ \\
\hline & Age category-yearling & $-0.429(0.302)$ & -1.419 & 0.156 & $0.7(0.4-1.2)$ \\
\hline & Age category_adult & $-0.534(0.257)$ & -2.077 & $0.038^{*}$ & $0.6\left(0.4-1.0^{b}\right)$ \\
\hline
\end{tabular}

a Final models on predicted effect of host traits and density on detection of the pathogens A. phagocytophilum, Bartonella spp., Babesia spp., Rickettsia spp. and the presence of co-infection in roe deer blood samples

${ }^{\mathrm{b}}$ The upper limit of this $95 \% \mathrm{Cl}$ is 0.964 , i.e., $95 \% \mathrm{Cl}$ excludes 1

*Statistically significant

Table 7 Host factor and density predictors for A. phagocytophilum $C_{t}$ load $<30(n=359)$

\begin{tabular}{llllll}
\hline Dependent variable & Model structure $^{\mathrm{a}}$ & Estimate $( \pm \mathrm{SE})$ & $z$ & $P$ & Odds ratio (95\% Cl) \\
\hline A. phagocytophilum & Intercept & $-0.349(0.201)$ & -1.738 & 0.082 & $0.7(0.5-1.0)$ \\
& Age category-yearling & $-0.535(0.323)$ & -1.657 & 0.097 & $0.6(0.3-1.1)$ \\
& Age category-adult & $-0.574(0.268)$ & -2.142 & $0.032^{*}$ & $0.6\left(0.3-1.0^{b}\right)$ \\
& Sex-male & $0.549(0.249)$ & 2.206 & $0.027^{*}$ & $1.7(1.1-2.8)$ \\
\hline
\end{tabular}

${ }^{a}$ Predicted effect of age category (calf, yearling, adult) and sex (female, male) for A. phagocytophilum $C_{t}$ load, subset data $(n=359)$. Model reference categories: age category: calf; sex: female

b The upper limit of this $95 \% \mathrm{Cl}$ is 0.95 , i.e., $95 \% \mathrm{Cl}$ excludes 1

*Statistically significant

Table 8 Host factor and density predictors for the number of co-infecting pathogens $(n=284)$

\begin{tabular}{llllll}
\hline Dependent variable & Model structure & Estimate $( \pm \mathrm{SE})$ & $t$ & $P$ & Odds ratio (95\% Cl) \\
\hline $\begin{array}{lllll}\text { Number of co-infecting } \\
\text { pathogens }^{\mathrm{b}}\end{array}$ & Intercept & $2.531(0.119)$ & 21.292 & $<0.001^{*}$ & $12.6(9.9-15.9)$ \\
& Age category-yearling & $-0.110(0.069)$ & -1.600 & 0.111 & $0.9\left(0.8-1.0^{\mathrm{C}}\right)$ \\
& Age category-adult & $-0.173(0.058)$ & -3.006 & $0.003^{*}$ & $0.8(0.8-0.9)$ \\
& Health status-healthy & $-0.222(0.117)$ & -1.899 & 0.059 & $0.8\left(0.6-1.0^{d}\right)$ \\
\hline
\end{tabular}

a Predicted effect of age category (calf, yearling, adult) and health (ill, healthy) on the number of co-infecting pathogens, subset data ( $n=284$ ). Model reference categories: age category: calf; health status: ill

${ }^{\mathrm{b}} R^{2}=0.033, P=0.006$

'The upper limit of this $95 \% \mathrm{Cl}$ is 0.1 .026 , i.e., $95 \% \mathrm{Cl}$ includes 1

${ }^{\mathrm{d}}$ The upper limit of this $95 \% \mathrm{Cl}$ is 0.1 .008 , i.e., $95 \% \mathrm{Cl}$ includes 1

*Statistically significant 
microti. Babesia capreoli infection has caused death in roe deer $[39,40]$. The detection of $B$. microti was not in line with expectations, as $B$. microti is primarily encountered in voles and mice, rather than in roe deer, in which B. microti-like pathogens have been found only once [36, 64]. High exposure of roe deer to tick bites can enable transient presence in roe deer blood of tick-associated microorganisms [65] or only their DNA. Babesia venatorum was not detected but may have been among the unknowns, because roe deer have been identified as one of the primary cervid reservoirs [33]. This study found a significant inverse effect of age, consistent with some studies elsewhere [17, 38]. Calves $(<1$ year old $)$ tested positive for Babesia spp. more frequently than older animals ( $\geq 1$ year old). In enzootic areas, animals infected with Babesia spp. at a young age may benefit from passive immunity acquired from the mother and become infected without the presence of clinical symptoms [39]. After primary infection, the infection may persist and in some pre-immunized animals might be reduced to below the level of detection [38]; alternatively, it could be cleared by the immune system, leading to long-term protective immunity which prevents reinfection with this protozoal pathogen [38]. Because of the negative association of Babesia with age and due to the low prevalence of Babesia spp., Babesia spp. is possibly locally enzootic in the Netherlands.

DNA of spotted fever Rickettsia was detected in 3.3\% of the roe deer. As further typing of these samples by conventional PCR failed, the rickettsial species could not be determined, and the prevalence found in this study was therefore difficult to compare with prior PCR findings where roe deer were tested for $R$. helvetica $[10,15$, 48]. The life-cycle of Rickettsia spp. primarily depends on transovarial transmission in vectors [66]. Hence, the relatively low prevalence found in this study may suggest that roe deer might incidentally act as a sporadic source of pathogens to vectors, relevant possibly only for spatial dissemination [67].

Genetic material was detected only once for B. burgdorferi s.l. and not for B. miyamotoi, or N. mikurensis. The incompetence of roe deer to function as reservoirs for B. burgdorferi s.l. and N. mikurensis corresponded with earlier studies [42, 43, 45, 46, 68, 69]. Also, none of the animals were found to be positive with BTV or EHDV, implicating neither were circulating within the Dutch roe deer population in 2010. BTV antibodies from previous years when BTV was present in the Netherlands would be expected only in adult roe deer in 2010 and may have waned. Moreover, others have reported low BTV seroprevalence in roe deer $[6,49,70]$, suggesting they are a less important species in the distribution of BTV in nature [70].
In multiple host vector-borne diseases, the associations between pathogen prevalence and host densities are complex, especially when vectors use different hosts in different life stages [20,71]. In this study, there was no evidence for an association of roe deer density with the presence or absence of the detected pathogens.

Various co-infections were encountered. The most dominant combinations included $A$. phagocytophilum and Bartonella spp., with or without Babesia spp. presence. Co-infections with two or three of these pathogens (Bartonella spp., A. phagocytophilum, Babesia spp.) have previously been documented in roe deer [10, 11, 17, 26, 35]. Co-infection of roe deer with A. phagocytophilum and Bartonella spp. or Babesia spp. occurred more frequently than could be expected by chance. For A. phagocytophilum and Babesia spp., one reason may be that they are transmitted by the same vector, I. ricinus. In addition, $A$. phagocytophilum infection is believed to induce immunosuppressive effects, resulting in an increase in the susceptibility to simultaneous infection with vector-borne pathogens that would normally be regulated by unimpaired lymphocytes and neutrophils [72]. In younger animals this mechanism might be most prominent, because premunition has not yet been acquired [73].

\section{Limitations}

Despite striving for random sampling of the roe deer population, operational challenges were encountered such as the dependency on hunters for sample submission and roe deer trait information, and the differential hunting seasons for does and calves compared to bucks. There was a slight but significant underrepresentation of bucks in the sample, largely due to a lower return rate of samples during the buck hunting season (59\% of the sample packages assigned to GMUs in buck hunting season) compared to the doe-and-calf hunting season $(69 \%$ of the sample packages assigned to GMUs in doe-and-calf hunting season). Interviews following the doe-and-calf hunting season indicated that organizational problems and suspended hunting activity are the main reasons given for the non-return of samples. Also, roe deer from GMUs with a low density ( $\leq 2$ roe deer per 100 ha) were underrepresented. This could be a possible source of bias for the measured prevalence of pathogens and the lack of association between their presence and roe deer density. Among the roe deer trait information that the hunters supplied, age, nutritional condition and health status were not measured but estimated. Body mass, however, was significantly positively associated with male sex, increasing age, better nutritional condition, healthy status and living in areas with lower roe deer densities. This finding confirmed expectations, supporting overall 
correspondence in host factor information supplied by the hunters.

The differential hunting season was an unavoidable, but possible, source of bias, given that greater tick activity can normally be expected in spring and summer when the buck hunting season occurs. Therefore, as detailed previously, a seasonal effect, for example greater tick load, cannot be excluded as explanation for the positive association between male sex and $A$. phagocytophilum load. However, any bias due to a greater tick load on bucks would only have weakened the inverse association between age category and presence of $A$. phagocytophilum, Babesia spp. or co-infection. In regard to the pathogens detected, both orbiviruses were only measured during the doe-and-calf hunting season and 2 years after the last documented presence of BTV-8 in the Netherlands. The absence in roe deer positive for BTV could therefore have resulted from the disappearance of antibodies over this period of time in roe deer of $>2$ years of age and absence in the younger ones.

The interpretation of the prevalence was impaired by the lack of ecotype characterisation of A. phagocytophilum, no identification of species involved in the possibly dual or multiple infections of Bartonella spp. and Babesia spp., and by the lack of species determination for many Bartonella and Rickettsia species. Finally, the identification of genetic material of pathogens does not necessarily identify an active infection in roe deer, but it is a strong indication that a microorganism has been present in the host.

\section{Conclusion}

This study has given valuable information on $A$. phagocytophilum, Bartonella spp., Babesia spp., Rickettsia spp., B. burgdorferi s.l., B. miyamotoi, N. mikurensis, EHDV prevalence and BTV seroprevalence in Dutch roe deer. The high levels of infection and co-infection implicate that roe deer are of importance in the nationwide transmission of individual and multiple vector-borne pathogens in the Netherlands. Caution is warranted, however, when extrapolating prevalence of $A$. phagocytophilum, Bartonella spp. and Babesia spp. to a potential impact on public health and livestock, as further genetic characterization of the pathogens is required for a proper understanding of possible implications [73]. Age and nutritional condition were found to be the most influential host variables in regard to the presence of vectorborne pathogens in roe deer. Vector-borne pathogen presence was not associated with local roe deer density.

\section{Abbreviations}

AIC: Akaike information criterion; BTV: Bluetongue virus; Cl: Confidence interval; $C_{q}$ : Cycle threshold; EHDV: Epizootic haemorrhagic disease virus; EDTA:
Ethylenediaminetetraacetic acid; GLM: Generalized linear model; GMU: Game management unit; LR: Linear regression; MLR: Multiple linear regression; NA: Not available; OR: Odds ratio; PCR: Polymerase chain reaction; s.l.: Sensu lato; $x^{2}$ : Chi-square.

\section{Supplementary Information}

The online version contains supplementary material available at https://doi. org/10.1186/s13071-022-05195-w.

\section{Additional file 1. VBD Excel file.}

Additional file 2. GMU Excel file.

Additional file 3. R-script.

Additional file 4. Table. Mean weight of sampled roe deer per age category per sex $(n=366)$.

Additional file 5. Sequence results.

\section{Acknowledgements}

We are grateful to all the hunters that were involved in the collection of deer samples and to the Royal Dutch Hunters' Association (KNJV) for the GMUrelated data, and to the researchers who gave valuable input or feedback with regards to the spatial and statistical analyses.

\section{Authors' contributions}

Conception and funding acquisition: JMR, PVR and HS. Sample collection: JMR and MM. Laboratory testing for pathogens: PvR, HS, AdB and MF. Data analysis: SRW, JvdB and JMR. Manuscript writing: SRW, JMR and HS. All authors read and approved the final manuscript.

\section{Funding}

This study was financially supported by the Dutch Ministry of Agriculture, Nature and Food Quality (LNV; verplichtingnummer 1400004212) and by the Dutch Ministry of Health, Welfare and Sport (VWS), by a grant from the European Interreg North Sea Region program, as part of the NorthTick project, and by the Faculty of Veterinary Medicine, Utrecht University. HS was financially supported by ZonMW as part of the project "Ticking on Pandora's Box, a study into tick-borne pathogens in Europe" (project no. 522003007). The funders had no role in the design of the study; in the collection, analysis or interpretation of data; in the writing of the manuscript; or in the decision to publish the results.

\section{Availability of data and materials}

Data supporting the conclusions of this article are included within the article and its additional files. A limited amount of DNA from roe deer samples is available upon reasonable request.

\section{Declarations}

Ethics approval and consent to participate

Approval of the work by an ethics committee is not required for the pathogen surveillance of dead wildlife.

\section{Consent for publication}

Not applicable.

\section{Competing interests}

The authors declare that they have no competing interests.

\section{Author details}

${ }^{1}$ Dutch Wildlife Health Centre, Department of Biomolecular Health Sciences, Faculty of Veterinary Medicine, Utrecht University, Utrecht, The Netherlands. ${ }^{2}$ Centre for Infectious Disease Control, National Institute for Public Health and the Environment, Bilthoven, The Netherlands. ${ }^{3}$ Department of Virology, Wageningen Bioveterinary Research, Wageningen University and Research, Lelystad, The Netherlands. ${ }^{4}$ Centre for Human Metabolomics, Department of Biochemistry, North-West University, Potchefstroom, South Africa. 
${ }^{5}$ Department of Population Health Sciences, Faculty of Veterinary Medicine, Utrecht University, Utrecht, The Netherlands.

Received: 28 September 2021 Accepted: 9 February 2022 Published online: 05 March 2022

\section{References}

1. Jones KE, Patel NG, Levy MA, Storeygard A, Balk D, Gittleman JL, et al. Global trends in emerging infectious diseases. Nature. 2008;451:990-3.

2. Medlock JM, Hansford KM, Bormane A, Derdakova M, Estrada-Peña A, George JC, et al. Driving forces for changes in geographical distribution of Ixodes ricinus ticks in Europe. Parasites Vectors. 2013;6:1-11.

3. Mysterud A, Jore S, Østerås O, Viljugrein H. Emergence of tick-borne diseases at northern latitudes in Europe: a comparative approach. Sci Rep. 2017:7:1-11.

4. Folly AJ, Dorey-Robinson D, Hernández-Triana LM, Phipps LP, Johnson N. Emerging threats to animals in the United Kingdom by arthropod-borne diseases. Front Vet Sci. 2020;7:1-19.

5. Sprong H, Hofhuis A, Gassner F, Takken W, Jacobs F, Van Vliet AJH, et al. Circumstantial evidence for an increase in the total number and activity of Borrelia-infected Ixodes ricinus in the Netherlands. Parasites Vectors. 2012:5:294.

6. Falconi C, López-Olvera JR, Gortázar C. BTV infection in wild ruminants, with emphasis on red deer: a review. Vet Microbiol. 2011;151:209-19.

7. Tomassone L, Berriatua E, De Sousa R, Duscher GG, Mihalca AD, Silaghi $C$, et al. Neglected vector-borne zoonoses in Europe: into the wild. Vet Parasitol. 2018;251:17-26.

8. Ree ontwikkelingen KNJV-WBE databank, Nieuwsbrief 8. In: De reeënpopulatie. Kenniscentrum Reeën. https://www.over-reeen.nl/de-leefo mgeving/populatie. Accessed 1 Sept 2020.

9. Liz JS, Sumner JW, Pfister K, Brossard M. PCR detection and serological evidence of granulocytic ehrlichial infection in roe deer (Capreolus capreolus) and chamois (Rupicapra rupicapra). J Clin Microbiol. 2002:40:892-7.

10. Overzier E, Pfister K, Herb I, Mahling M, Böck G, Silaghi C. Detection of tick-borne pathogens in roe deer (Capreolus capreolus), in questing ticks (Ixodes ricinus), and in ticks infesting roe deer in southern Germany. Ticks Tick Borne Dis. 2013;4:320-8.

11. Welc-Falęciak R, Werszko J, Cydzik K, Bajer A, Michalik J, Behnke JM. Coinfection and genetic diversity of tick-borne pathogens in roe deer from Poland. Vector-Borne Zoonotic Dis. 2013;13:277-88.

12. Michalik J, Stańczak J, Racewicz M, Cieniuch S, Sikora B, SzubertKruszyńska A, et al. Molecular evidence of Anaplasma phagocytophilum infection in wild cervids and feeding Ixodes ricinus ticks from west-central Poland. Clin Microbiol Infect. 2009;15:81-3.

13. Petrovec M, SixI W, Schweiger R, Mikulašek S, Elke L, Wüst G, et al. Infections of wild animals with Anaplasma phagocytophila in Austria and the Czech Republic. Ann NY Acad Sci. 2003;990:103-6.

14. Polin H, Hufnagl P, Haunschmid R, Gruber F, Ladurner G. Molecular Evidence of Anaplasma phagocytophilum in Ixodes ricinus ticks and wild animals in Austria. J Clin Microbiol. 2004;42:2285-6.

15. Skarphédinsson S, Jensen PM, Kristiansen K. Survey of tickborne infections in Denmark. Emerg Infect Dis. 2005;11:1055-61.

16. Petrovec M, Bidovec A, Sumner JW, Nicholson WL, Childs JE, Avsic-Zupanc T. Infection with Anaplasma phagocytophila in cervids from Slovenia: evidence of two genotypic lineages. Wien Klin Wochenschr. 2002;114:641-7.

17. Kauffmann M, Rehbein S, Hamel D, Lutz W, Heddergott M, Pfister K, et al. Anaplasma phagocytophilum and Babesia spp. in roe deer (Capreolus capreolus), fallow deer (Dama dama) and mouflon (Ovis musimon) in Germany. Mol Cell Probes. 2017;31:46-54.

18. Remesar S, Díaz P, Prieto A, García-Dios D, Fernández G, López CM, et al. Prevalence and molecular characterization of Anaplasma phagocytophilum in roe deer (Capreolus capreolus) from Spain. Ticks Tick Borne Dis. 2020;11:101351.

19. Jahfari S, Coipan EC, Fonville M, Van Leeuwen AD, Hengeveld P, Heylen D, et al. Circulation of four Anaplasma phagocytophilum ecotypes in Europe. Parasites Vectors. 2014;7:1-11.

20. Stuen S, Granquist EG, Silaghi C. Anaplasma phagocytophilum-a widespread multi-host pathogen with highly adaptive strategies. Front Cell Infect Microbiol. 2013;3:31.
21. Woldehiwet Z. The natural history of Anaplasma phagocytophilum. Vet Parasitol. 2010;167:108-22.

22. Di Domenico M, Pascucci I, Curini V, Cocco A, Dall'Acqua F, Pompilii C, et al. Detection of Anaplasma phagocytophilum genotypes that are potentially virulent for human in wild ruminants and Ixodes ricinus in Central Italy. Ticks Tick Borne Dis. 2016;7:782-7.

23. Coipan EC, Jahfari S, Fonville M, Maassen CB, van der Giessen J, Takken W, et al. Spatiotemporal dynamics of emerging pathogens in questing Ixodes ricinus. Front Cell Infect Microbiol. 2013:4:1-11.

24. Breitschwerdt EB. Bartonellosis, One Health and all creatures great and small. Vet Dermatol. 2017;28:96-e21.

25. Razanske I, Rosef O, Radzijevskaja J, Klepeckiene K, Lipatova I, Paulauskas A. Infections with Bartonella spp. in free-ranging cervids and deer keds (Lipoptena cervi) in Norway. Comp Immunol Microbiol Infect Dis. 2018;58:26-30.

26. Skotarczak B, Adamska M. Detection of Bartonella DNA in roe deer (Capreolus capreolus) and in ticks removed from deer. Eur J Wildl Res. 2005;51:287-90.

27. Dehio C, Lanz C, Pohl R, Behrens P, Bermond D, Piémont Y, et al. Bartonella schoenbuchii sp. nov., isolated from the blood of wild roe deer. Int J Syst Evol Microbiol. 2001;51:1557-65.

28. Tijsse-Klasen E, Fonville M, Gassner F, Nijhof A, Hovius E, Jongejan F, et al. Absence of zoonotic Bartonella species in questing ticks: First detection of Bartonella clarridgeiae and Rickettsia felis in cat fleas in the Netherlands. Parasites Vectors. 2011;4:61.

29. Regier Y, Komma K, Weigel M, Pulliainen AT, Göttig S, Hain T, et al. Microbiome analysis reveals the presence of Bartonella spp. and Acinetobacter spp. in deer keds (Lipoptena cervi). Front Microbiol. 2018;9:1-10.

30. Bonnet S, Jouglin M, L'Hostis M, Chauvin A. Babesia sp. EU1 from roe deer and transmission within Ixodes ricinus. Emerg Infect Dis. 2007:13:1208-10.

31. Hrazdilová K, Rybářová M, Široký P, Votýpka J, Zintl A, Burgess H, et al. Diversity of Babesia spp in cervid ungulates based on the 18S rDNA and cytochrome c oxidase subunit I phylogenies. Infect Genet Evol. 2020;77:104060.

32. Remesar S, Díaz P, Prieto A, Markina F, Díaz Cao JM, López-Lorenzo G, et al. Prevalence and distribution of Babesia and Theileria species in roe deer from Spain. Int J Parasitol Parasites Wildl. 2019:9:195-201.

33. Duh D, Petrovec M, Bidovec A, Avsic-Zupanc T. Cervids as Babesiae hosts, Slovenia. Emerg Infect Dis. 2005;11:1121-3.

34. Malandrin L, Jouglin M, Sun Y, Brisseau N, Chauvin A. Redescription of Babesia capreoli (Enigk and Friedhoff, 1962) from roe deer (Capreolus capreolus): Isolation, cultivation, host specificity, molecular characterisation and differentiation from Babesia divergens. Int J Parasitol. 2010;40:277-84.

35. Silaghi C, Hamel D, Pfister K, Rehbein S. Babesia species and co-infection with Anaplasma phagocytophilum in free-ranging ungulates from Tyrol (Austria). Wien Tierarztl Monatsschr. 2011;98:268-74.

36. Tampieri MP, Galuppi R, Bonoli C, Cancrini G, Moretti A, Pietrobelli M. Wild ungulates as Babesia hosts in Northern and Central Italy. Vector-Borne Zoonotic Dis. 2008:8:667-74.

37. García-Sanmartín J, Aurtenetxe O, Barral M, Marco I, Lavin S, García-Pérez $\mathrm{AL}$, et al. Molecular detection and characterization of piroplasms infecting cervids and chamois in Northern Spain. Parasitology. 2007;134:391-8.

38. Michel AO, Mathis A, Ryser-Degiorgis MP. Babesia spp. in European wild ruminant species: parasite diversity and risk factors for infection. Vet Res. 2014:45:1-11

39. Penzhorn BL. Babesiosis of wild carnivores and ungulates. Vet Parasitol. 2006;138:11-21.

40. Hinaidy HK. Blutparasiten der wildlebenden Wiederkäuer Österreichs. J Vet Med Ser B. 1987;34:81-97.

41. Jahfari S, Sprong H. Emerging tick-borne pathogens: ticking on Pandora's box. In: Ecology and prevention of Lyme borreliosis. Wageningen Academic Publishers. 2016:4:119-22.

42. Jaenson TGT, Tälleklint L. Incompetence of roe deer (Capreolus capreolus) as reservoirs of the Lyme disease spirochete. J Med Entomol. 1992;29:813-7.

43. Rosef O, Paulauskas A, Radzijevskaja J. Prevalence of Borrelia burgdorferi sensu lato and Anaplasma phagocytophilum in questing Ixodes ricinus ticks in relation to the density of wild cervids. Acta Vet Scand. 2009;51:47. 
44. Wagemakers A, Staarink PJ, Sprong H, Hovius JWR. Borrelia miyamotoi: a widespread tick-borne relapsing fever spirochete. Trends Parasitol. 2015;31:260-9.

45. Silaghi C, Beck R, Oteo JA, Pfeffer M, Sprong H. Neoehrlichiosis: an emerging tick-borne zoonosis caused by Candidatus Neoehrlichia mikurensis. Exp Appl Acarol. 2016;68:279-97.

46. Beck R, Čurik V, Ivana R, Nikica Š, Anja V. Identification of "Candidatus Neoehrlichia mikurensis" and Anaplasma species in wildlife from Croatia. Parasit Vectors. 2014;7:028.

47. Jahfari S, Fonville M, Hengeveld P, Reusken C, Scholte EJ, Takken W, et al. Prevalence of Neoehrlichia mikurensis in ticks and rodents from Northwest Europe. Parasites Vectors. 2012;5:1-10.

48. Sprong $\mathrm{H}$, Wielinga PR, Fonville $\mathrm{M}$, Reusken $\mathrm{C}$, Brandenburg $\mathrm{AH}$, Borgs-

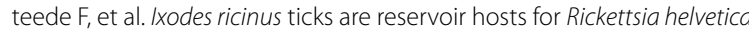
and potentially carry flea-borne Rickettsia species. Parasites Vectors. 2009;2:1-7.

49. Linden A, Grégoire F, Nahayo A, Hanrez D, Mousset B, Massart L, et al. Bluetongue virus in wild deer, Belgium, 2005-2008. Emerg Infect Dis. 2010;16:833-6.

50. Gibbs EPJ, Lawman MJP. Infection of British deer and farm animals with epizootic haemorrhagic disease of deer virus. J Comp Pathol. 1977;87:335-43.

51. Arenas-Montes AJ, Arenas A, García-Bocanegra I, Mertens P, Batten C, Nomikou K. Serosurveillance of orbiviruses in wild cervids from Spain. Vet Rec. 2013;172:508-9.

52. Heylen D, Tijsse E, Fonville M, Matthysen E, Sprong H. Transmission dynamics of Borrelia burgdorferi s.l. in a bird tick community. Environ Microbiol. 2013;15:663-73.

53. Hovius JWR, De Wever B, Sohne M, Brouwer MC, Coumou J, Wagemakers A, et al. A case of meningoencephalitis by the relapsing fever spirochaete Borrelia miyamotoi in Europe. Lancet. 2013;382:658.

54. Stenos J, Graves SR, Unsworth NB. A highly sensitive and specific realtime PCR assay for the detection of spotted fever and typhus group Rickettsiae. Am J Trop Med Hyg. 2005;73:1083-5.

55. Wielinga PR, Fonville M, Sprong H, Gaasenbeek C, Borgsteede F, van der Giessen JWB. Persistent detection of Babesia EU1 and Babesia microti in Ixodes ricinus in the Netherlands during a 5-year surveillance: 2003-2007. Vector-Borne Zoonotic Dis. 2009;9:119-21.

56. De Sousa R, Edouard-Fournier P, Santos-Silva M, Amaro F, Bacellar F, Raoult D. Molecular detection of Rickettsia felis, Rickettsia typhi and two genotypes closely related to Bartonella elizabethae. Am J Trop Med Hyg. 2006;75:727-31.

57. Coipan EC, Fonville M, Tijsse-Klasen E, van der Giessen JW, Takken W, Sprong $\mathrm{H}$, et al. Geodemographic analysis of Borrelia burgdorferi sensu lato using the 5S-23S rDNA spacer region. Infect Genet Evol. 2013:17:216-22.

58. Alberdi MP, Walker AR, Urquhart KA. Field evidence that roe deer (Capreolus capreolus) are a natural host for Ehrlichia phagocytophila. Epidemiol Infect. 2000;124:315-23.

59. Stigum VM, Jaarsma RI, Sprong H, Rolandsen CM, Mysterud A. Infection prevalence and ecotypes of Anaplasma phagocytophilum in moose Alces alces, red deer Cervus elaphus, roe deer Capreolus capreolus and Ixodes ricinus ticks from Norway. Parasit Vectors. 2019;12:1-8.

60. Fabri ND, Sprong H, Hofmeester TR, Heesterbeek H, Donnars BF, Widemo $F$, et al. Wild ungulate species differ in their contribution to the transmission of Ixodes ricinus-borne pathogens. Parasit Vectors. 2021;14:1-15.

61. Dwużnik-Szarek D, Kowalec M, Alsarraf M, Bajer A. Contribution of tick-borne diseases to mortality in juvenile free-living cervids. Ann Agric Environ Med. 2021.

62. Schulz M, Mahling M, Pfister K. Abundance and seasonal activity of questing Ixodes ricinus ticks in their natural habitats in southern Germany in 2011. J Vector Ecol. 2014;39:56-65.

63. Corlatti L, Béthaz S, von Hardenberg A, Bassano B, Palme R, Lovari S. Hormones, parasites and male mating tactics in Alpine chamois: identifying the mechanisms of life history trade-offs. Anim Behav. 2012;84:1061-70.

64. Duh D, Petrovec M, Trilar T, Avsic-Zupanc T. The molecular evidence of Babesia microti infection in small mammals collected in Slovenia. Parasitology. 2003;126:113-7.

65. Serra V, Cafiso A, Formenti N, Verheyden H, Plantard O, Bazzocchi C, et al. Molecular and serological evidence of the presence of Midichloria mitochondrii in roe deer (Capreolus capreolus) in France. J Wildl Dis. 2018;54:597-600.

66. Raoult D, Roux V. Rickettsioses as paradigms of new or emerging infectious diseases. Clin Microbiol Rev. 1997;10:694-719.

67. Elfving K, Malmsten J, Dalin AM, Nilsson K. Serologic and molecular prevalence of Rickettsia helvetica and Anaplasma phagocytophilum in wild cervids and domestic mammals in the central parts of Sweden. VectorBorne Zoonotic Dis. 2015;15:529-34.

68. Beninati T, Piccolo G, Rizzoli A, Genchi C, Bandi C. Anaplasmataceae in wild rodents and roe deer from Trento Province (northern Italy). Eur J Clin Microbiol Infect Dis. 2006:25:677-8.

69. Wodecka B, Rymaszewska A, Skotarczak B. Host and pathogen DNA identification in blood meals of nymphal Ixodes ricinus ticks from forest parks and rural forests of Poland. Exp Appl Acarol. 2014;62:543-55.

70. García-Bocanegra I, Arenas-Montes A, Lorca-Orá C, Pujols J, González M, Napp $S$, et al. Role of wild ruminants in the epidemiology of bluetongue virus serotypes 1, 4 and 8 in Spain. Vet Res. 2011;42:1-7.

71. Rosà R, Pugliese A. Effects of tick population dynamics and host densities on the persistence of tick-borne infections. Math Biosci. 2007;208:216-40.

72. Brown WC, Barbet AF. Persistent infections and immunity in ruminants to arthropod-borne bacteria in the family Anaplasmataceae. Annu Rev Anim Biosci. 2016:4:177-97.

73. Chastagner A, Pion A, Verheyden H, Lourtet B, Cargnelutti B, Picot D, et al. Host specificity, pathogen exposure, and superinfections impact the distribution of Anaplasma phagocytophilum genotypes in ticks, roe deer, and livestock in a fragmented agricultural landscape. Infect Genet Evol. 2017:55:31-44.

\section{Publisher's Note}

Springer Nature remains neutral with regard to jurisdictional claims in published maps and institutional affiliations.
Ready to submit your research? Choose BMC and benefit from:

- fast, convenient online submission

- thorough peer review by experienced researchers in your field

- rapid publication on acceptance

- support for research data, including large and complex data types

- gold Open Access which fosters wider collaboration and increased citations

- maximum visibility for your research: over $100 \mathrm{M}$ website views per year

At BMC, research is always in progress.

Learn more biomedcentral.com/submissions 